\title{
Nitrogen pollution and source identification of urban ecosystem surface water in Beijing
}

\author{
Yufen REN ${ }^{1 *}$, Zhiwei XU ${ }^{2,3 *}$, Xinyu ZHANG $(\bowtie)^{2}$, Xiaoke WANG ${ }^{1}$, Xiaomin SUN ${ }^{2}$, \\ D. J. BALLANTINE ${ }^{4}$, Shengzhong WANG ${ }^{3}$ \\ 1 State Key Laboratory of Urban and Regional Ecology, Research Center for Eco-Environmental Sciences, \\ Chinese Academy of Sciences, Beijing 100085, China \\ 2 Key Laboratory of Ecosystem Network Observation and Modeling, Institute of Geographic Sciences and Natural Resources Research, \\ Chinese Academy of Sciences, Beijing 100101, China \\ 3 College of Urban and Environmental Science, Northeast Normal University, Changchun 130024, China \\ 4 National Institute of Water and Atmospheric Research, Hamilton 3216, New Zealand
}

(C) Higher Education Press and Springer-Verlag Berlin Heidelberg 2013

\begin{abstract}
Nitrogen contamination of surface water is a worldwide environmental problem with intensive agriculture and high population densities. We assessed the spatial and seasonal variation in concentrations of total nitrogen and different nitrogen species present in surface-water in Beijing, China. Also, chemical $\left(\mathrm{NO}_{3}^{-}-\mathrm{N} / \mathrm{Cl}^{-}\right)$and isotopic $\left(\delta^{15} N_{\text {nitrate }}\right)$ indicators were used to identify nitrate sources. The results showed that, during 2009 and 2010, nitrate nitrogen concentrations ranged from 0.7 to $7.6 \mathrm{mg}$ $\cdot \mathrm{L}^{-1}$, ammonium nitrogen from 0.1 to $3.4 \mathrm{mg} \cdot \mathrm{L}^{-1}$, and total nitrogen from 2.4 to $17.0 \mathrm{mg} \cdot \mathrm{L}^{-1}$. Inorganic nitrogen accounted for between 60 and $100 \%$ of total nitrogen at the ten monitoring sites. Nitrate nitrogen, ammonium nitrogen, and total nitrogen concentrations at the 2 downstream monitoring sites in south-eastern Beijing were significantly higher than those at the other eight upstream monitoring sites $(P<0.01)$. Examination of seasonal variation showed that there was a significant inverse relationship between nitrate nitrogen concentrations and precipitation, and that nitrate nitrogen concentrations peaked in the dry seasons. The information given by the $\delta^{15} \mathrm{~N}_{\text {nitrate }}$ values and nitrate nitrogen concentrations, combined with the $\mathrm{NO}_{3}^{-}-\mathrm{N} / \mathrm{Cl}^{-}$ ratio distribution, showed that domestic sewage was the major source of nitrate in Beijing. Methods to control and reduce sewage pollution are urgently needed to help manage surface water quality in Beijing.
\end{abstract}

Received January 18, 2012; accepted November 6, 2012

E-mail: zhangxy@igsnrr.ac.cn

${ }^{*}$ These authors contributed equally to this work.
Keywords nitrogen concentration, spatial and seasonal variation, stable nitrogen isotope, urban ecosystem, source

\section{Introduction}

Nitrogen $(\mathrm{N})$ pollution poses a serious threat to fresh water supplies and promotes eutrophication [1,2]. Possible sources of nitrogen contamination in surface water include manure applied to land, agricultural fertilizer, industrial effluent, domestic sewage, septic systems, human waste lagoons, animal feedlots, and native soil organic matter [3], as well as elevated atmospheric $\mathrm{N}$ deposition [4]. Urban environments are of great concern because of the high population densities and the immediate proximity of typical urban nitrogen sources, for example, wastewater disposal (onsite systems and leaky sewers) and solid waste disposal (landfills and waste tips) [5]. Sources of nitrogen in urban surface water must be identified before an efficient remediation plan can be devised.

With the growth of urban and suburban areas, urban surface water has become increasingly seriously polluted. A survey of streams and rivers [6] in Washington found that nitrate concentrations were significantly higher in urban watersheds than in partially developed and undeveloped watersheds.

It has also been reported that concentrations of dissolved organic nitrogen (from septic systems) in tributaries with residential development peaked during spring snow melt, and that between 19 and $23 \%$ of the annual $\mathrm{N}$ export from developed tributaries was derived from septic systems, as estimated from the $\delta^{15} \mathrm{~N}$ of algae [7]. Groffman et al. [8] reported that urban and suburban watersheds had much 
higher $\mathrm{N}$ losses than did completely forested watersheds (less than $1 \mathrm{~kg} \mathrm{~N} \cdot \mathrm{ha}^{-1} \cdot \mathrm{a}^{-1}$ ), with $\mathrm{N}$ yields ranging from 2.9 to $7.9 \mathrm{~kg} \mathrm{~N} \cdot \mathrm{ha}^{-1} \cdot \mathrm{a}^{-1}$. Research has shown that the $\mathrm{NO}_{3}^{-}-\mathrm{N}$ concentrations in most rivers in populated regions could reach levels that are seven times higher than the $10 \mathrm{mg}$ $\cdot \mathrm{L}^{-1}$ guideline of the Global Environment Monitoring System (GEMS) database [9]. In China, surface water in urban areas such as Shanghai, Tianjin, Changshu, Xi'an, Guangzhou and Hangzhou is polluted to different degrees, and nitrate and total nitrogen are among the major pollutants [10-15].

In 2006 it was reported that about $60 \%$ of the rivers, lakes and reservoirs in Beijing, China were seriously polluted [16], with large areas of algal blooms present in surface water in Beijing [17]. Until now however, few studies have investigated or identified sources of nitrogen in surface water in Beijing. In this study, to address this gap in knowledge, an isotope tracing method has been combined with chemical indicators to examine the sources of nitrogen in surface water in Beijing. The objectives of this study were to (i) assess the spatial and seasonal variation of nitrogen contamination, and (ii) identify the main sources of anthropogenic nitrogen pollution in surface water in Beijing. Findings from this study will provide key information that will be useful in controlling nitrogen pollution in surface water in Beijing, and in promoting sustainable water management in urban Beijing.

\section{Methods}

\subsection{Study area descriptions}

The study area $\left(39^{\circ} 53^{\prime}\right.$ to $39^{\circ} 59^{\prime} \mathrm{N}, 116^{\circ} 11^{\prime}$ to $\left.116^{\circ} 35^{\prime} \mathrm{E}\right)$ has a temperate territorial semi-humid climate. The annual average temperature is $12.7^{\circ} \mathrm{C}$, and annual mean precipitation is about $562 \mathrm{~mm}$, most of which occurs during the summer monsoon season from July to August. The annual mean evaporation is $1833 \mathrm{~mm}$. The urban area of Beijing is about $1000 \mathrm{~km}^{2}$, which is almost 17 times what it was in 1949. In 2010 , the permanent population was approximately 20 million people [18].

Rivers mostly flow from the north-west to the south-east in Beijing. The surface water monitoring sites chosen for this study are shown in Fig. 1, and were located on the Kunminghu Lake, Chang, Zhuan, Beihucheng River, Qianhai Lake, Changpu, Donghucheng and Tonghui Rivers, and covered a drainage area of $250 \mathrm{~km}^{2}$. The

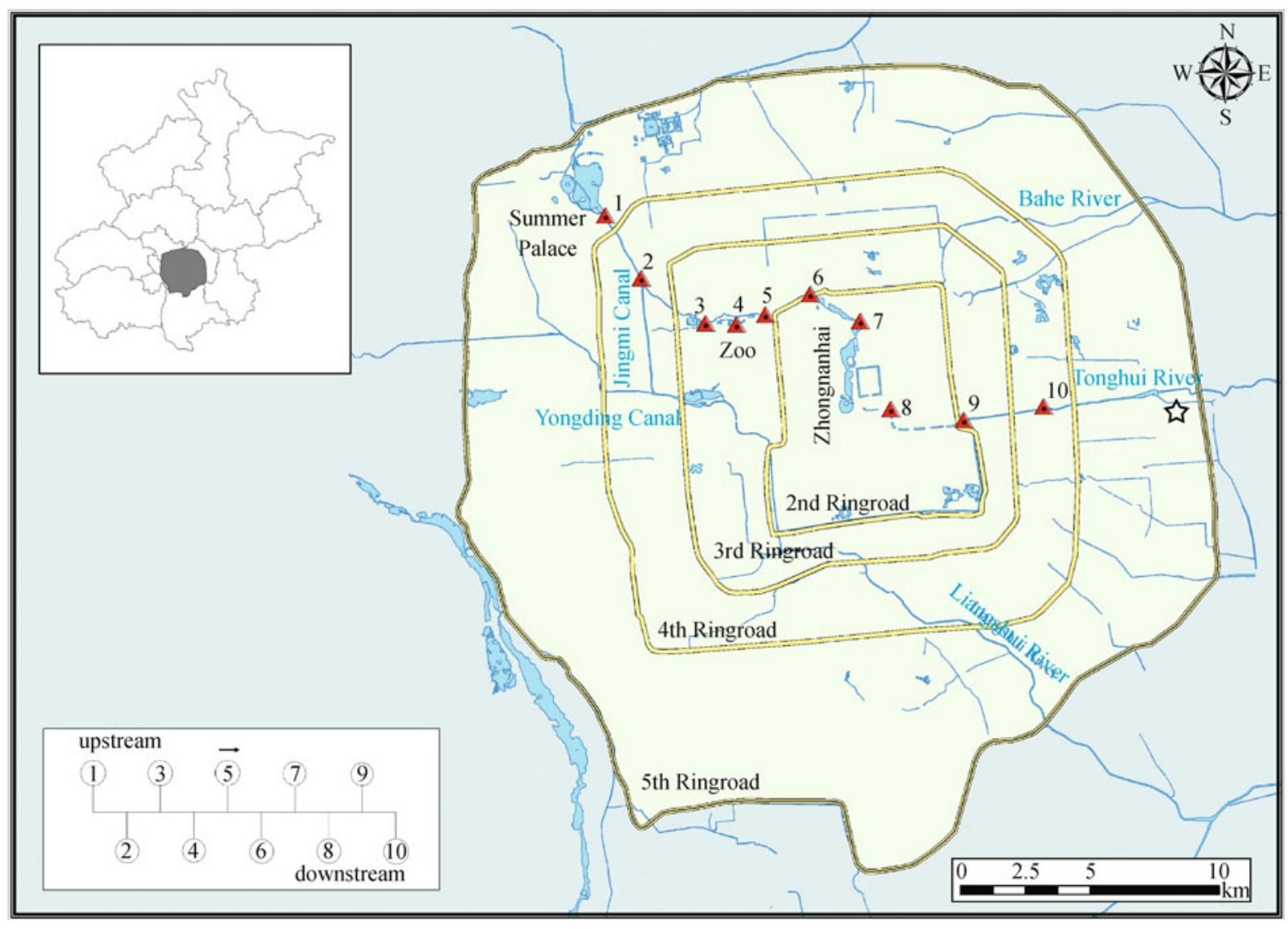

Fig. 1 Surface water sampling sites in the Beijing urban area. "1-10" represent " Kunminghu, Changchunqiao, Library, Zoo, Zhuanhe, Huchenghe, Qianhai, Changpuhe, Dongbianmen and Tonghuihe, respectively. " ¿s " in the figure represent Gaobeidian Sewage Treatment Plant 
land around the Kunminghu Lake and Changchunqiao Bridge sampling sites is largely greenbelt, but from Library to Tonghuihe River, land use is mainly residential or commercial.

The Gaobeidian wastewater treatment plant is situated near the Tonghuihe monitoring site on the Tonghui River. It is the biggest wastewater treatment plant in China, collecting most of the domestic sewage and industrial wastewater from southern Beijing. Because of the effect of sluice gate of Gaobeidian reservoir, most of the processed wastewater flow to the upstream of the treatment plant. Upstream of the treatment plant, the average DO values are all above $10 \mathrm{mg} \cdot \mathrm{L}^{-1}$, but fall to $7 \mathrm{mg} \cdot \mathrm{L}^{-1}$ downstream of the treatment plant (at Dongbianmen and Tonghuihe). The average COD value upstream of the plant (from Kunminghu to Qianhai) was $30 \mathrm{mg} \cdot \mathrm{L}^{-1}$ but increased to an average of $104 \mathrm{mg} \cdot \mathrm{L}^{-1}$ and $72 \mathrm{mg} \cdot \mathrm{L}^{-1}$ at the Dongbianmen and Tonghuihe monitoring sites respectively (unpublished data from the CERN Beijing urban station collected from 2009 to 2010). When compared to the National Environmental Quality Standards for Surface Waters in China [19], COD values recorded at the Dongbianmen and Tonghuihe monitoring sites far exceed the class five guideline values $\left(\mathrm{COD} \leqslant 40 \mathrm{mg} \cdot \mathrm{L}^{-1}\right)$, indicating severely polluted conditions.

\subsection{Monitoring and analysis methods}

Bi-monthly samples were collected from 2009 to 2011. Nitrate nitrogen $\left(\mathrm{NO}_{3}^{-}-\mathrm{N}\right)$ and chloride $\left(\mathrm{Cl}^{-}\right)$concentrations were measured using a Shimadzu Ion Chromatograph meter. Ammonium $\left(\mathrm{NH}_{4}^{+}\right)$was analyzed by spectrophotometer. Concentrations of total nitrogen (TN) were determined by potassium persulfate digestion and measured by spectrophotometer. Dissolved organic nitrogen (DON) concentrations were calculated by subtraction as follows: $\mathrm{TN}-\left(\mathrm{NO}_{3}^{-}-\mathrm{N}+\mathrm{NH}_{4}^{+}-\mathrm{N}\right)$.

The stable isotopic composition of nitrate $\left(\delta^{15} \mathrm{~N}_{\text {nitrate }}\right)$ was measured using an anion exchange resin method [20]. The $\delta^{15} \mathrm{~N}_{\text {nitrate }}$ values were determined using a Finnigan MAT253 mass spectrometer with an online Flash Elemental Analyzer, and reported in the $\delta$ notation relative to $\mathrm{N}_{2}$ (air) and Standard Mean Ocean Water (SMOW) in permil (\%). USGS-32 (Potassium nitrate) was used as a standard to check the anion exchange method and analysis accuracy. The isotope results are given in $\delta$ units defined as Equation 1:

$$
\delta(\%)=\left(\left(R_{\text {sample }} / R_{\text {standard }}\right)-1\right) \times 1000,
$$

where $R$ represents the ${ }^{15} \mathrm{~N} /{ }^{14} \mathrm{~N}$ ratio.

\subsection{Identification of nitrate sources}

The stable isotope method can provide effective informa- tion on nitrate sources due to the distinctive nitrogen ratio of the main nitrate sources, such as precipitation, sewage, organic fertilizer, chemical fertilizer and nitrate from nitrification $[21,22]$. Inorganic fertilizers are produced by fixation of atmospheric $\mathrm{N}_{2}$ and show small differences in $\delta^{15} \mathrm{~N}$ content as a result of the small fractionation during processing of the fixed $\mathrm{N}$ [23]. These fertilizers show a typical $\delta^{15} \mathrm{~N}$ value range of between $-6 \%$ and $+6 \%$ [24]. Typical $\delta^{15} \mathrm{~N}$ values of atmospheric $\mathrm{N}$ deposition lie between $-13 \%$ and $+13 \%$ [22]. Manure and sewage are rich in $\delta^{15} \mathrm{~N}$ relative to other $\mathrm{N}$ sources. During storage, treatment and application of sewage and animal wastes, ammonia $\left(\mathrm{NH}_{3}\right)$ volatilization causes a large enrichment of ${ }^{15} \mathrm{~N}$ in the residual $\mathrm{NH}_{4}^{+}$. This $\mathrm{NH}_{4}^{+}$is subsequently converted into ${ }^{15} \mathrm{~N}$-enriched $\mathrm{NO}_{3}^{-}$. Thus, $\delta^{15} \mathrm{~N}$ values of $\mathrm{NH}_{3}^{-}$originating from manure are between $+5 \%$ and $+25 \%$ and sewage between $+4 \%$ and $+19 \%$ [24]. The typical $\delta^{15} \mathrm{~N}$ values of soil $\mathrm{N}$ range from $0 \%$ to $+8 \%$ [24]. Finally, $\delta^{15} \mathrm{~N}$ values of $\mathrm{NO}_{3}^{-}$in industrial wastewater vary between $11 \%$ and $23 \%$ [25].

\subsection{Statistical analysis}

A one-way analysis of variance (ANOVA) (using a least significant difference (LSD) post-hoc test) was used to analyze the spatial variations in concentrations of $\mathrm{N}$ and $\mathrm{N}$ fractions between the surface water sampling sites in Beijing. Correlation analyses were conducted to explore the relationships between nitrogen and monthly mean rainfall. All statistics were analyzed by SPSS 17.0 software.

\section{Results}

\subsection{Spatial variation of different species of nitrogen} concentrations

The average nitrate nitrogen concentrations at the Dongbianmen and Tonghuihe River monitoring sites ranged from 7.0 to $7.6 \mathrm{mg} \cdot \mathrm{L}^{-1}$, while those from the Kunminghu Lake to the Changpuhe River ranged from 0.7 to $3.4 \mathrm{mg} \cdot \mathrm{L}^{-1}$ (Fig. 2(a). Ammonium nitrogen concentrations were also significantly higher in the lower reaches at the Dongbianmen and Tonghuihe monitoring sites (3.3 and $3.4 \mathrm{mg} \cdot \mathrm{L}^{-1}$, respectively) than those at the other 8 monitoring sites in the upper reaches (where they ranged from 0.1 to $\left.\left.0.5 \mathrm{mg} \cdot \mathrm{L}^{-1}\right)(P<0.01)\right)$ (Fig. 2(b)). Dissolved organic nitrogen concentrations ranged from 0.3 to $2.4 \mathrm{mg}$ $\cdot \mathrm{L}^{-1}$, with the highest values found at the Qianhai, Dongbianmen and Tonghuihe monitoring sites (Fig. 2 (c)). Total nitrogen concentrations from the Kunminghu Lake to the Changpuhe River were from 2.4 to $4.5 \mathrm{mg} \cdot \mathrm{L}^{-1}$, but increased to $17 \mathrm{mg} \cdot \mathrm{L}^{-1}$ in the Dongbianmen and the Tonghuihe Rivers (Fig. 2(d)). Nitrate nitrogen, ammonium 


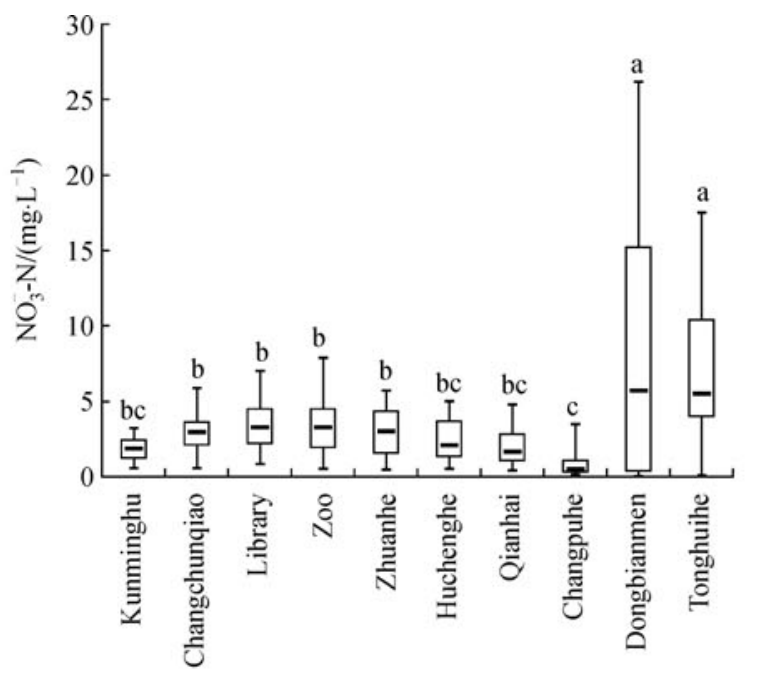

(a)

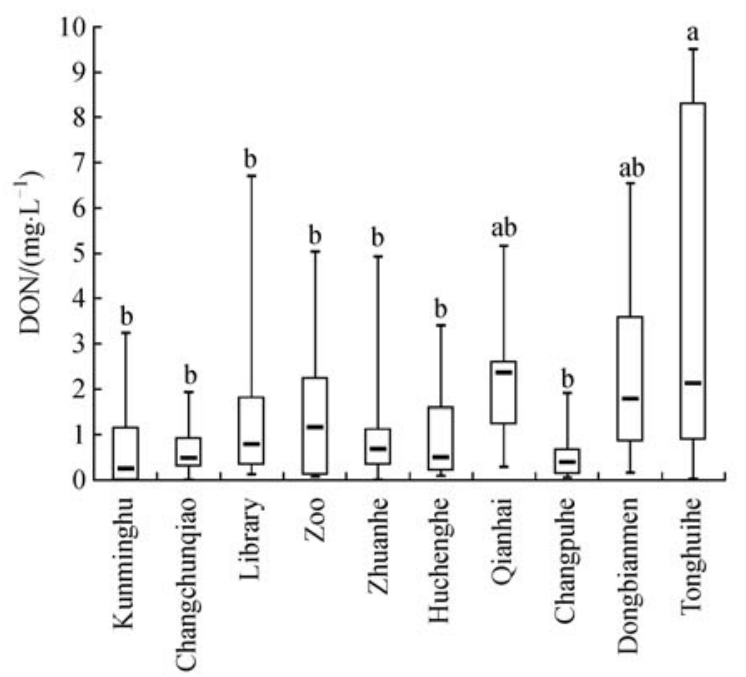

(c)

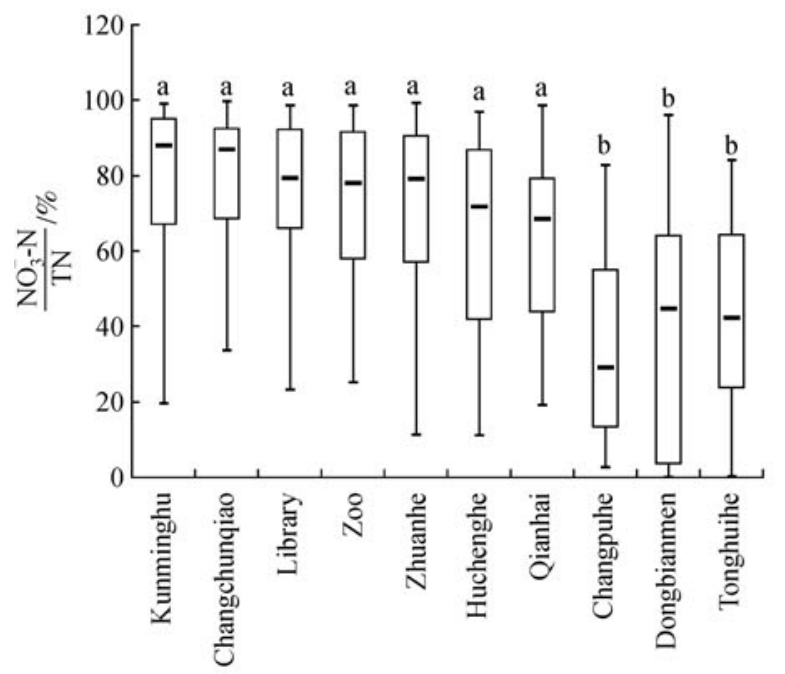

(e)

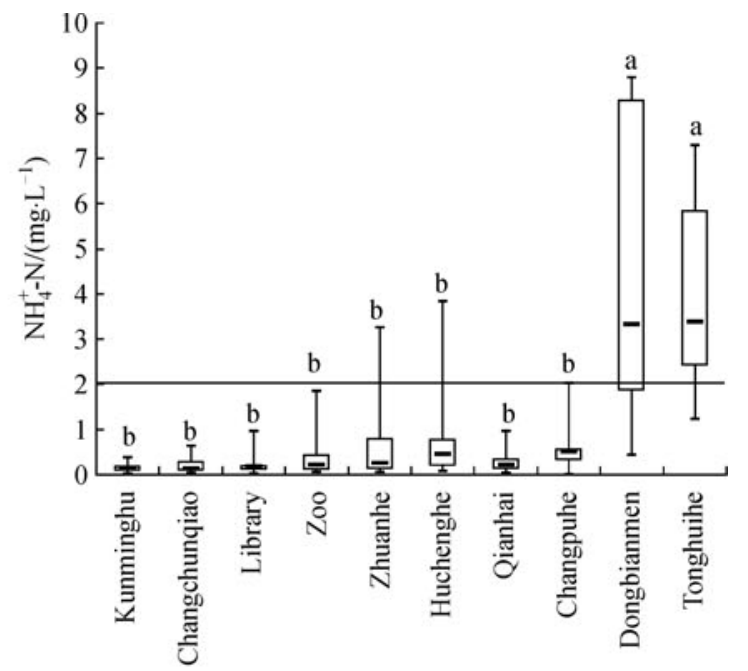

(b)

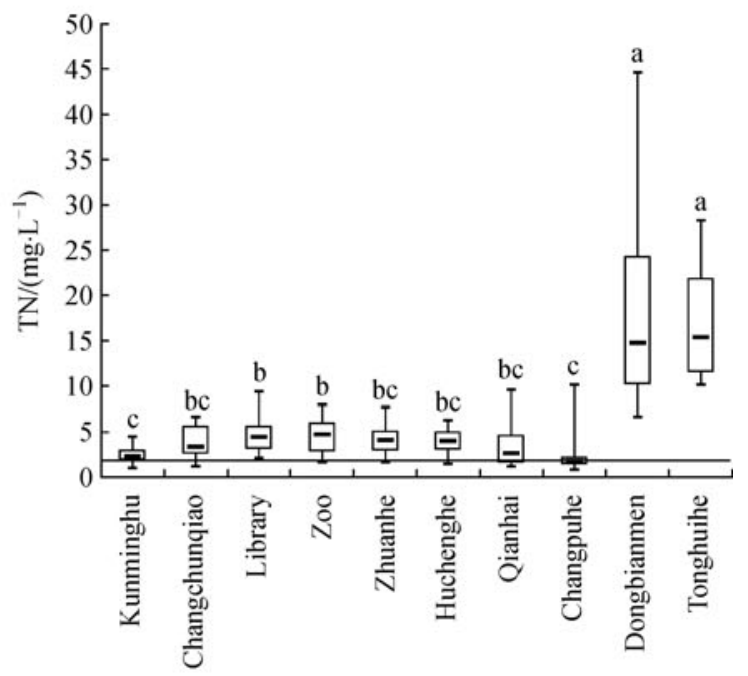

(d)

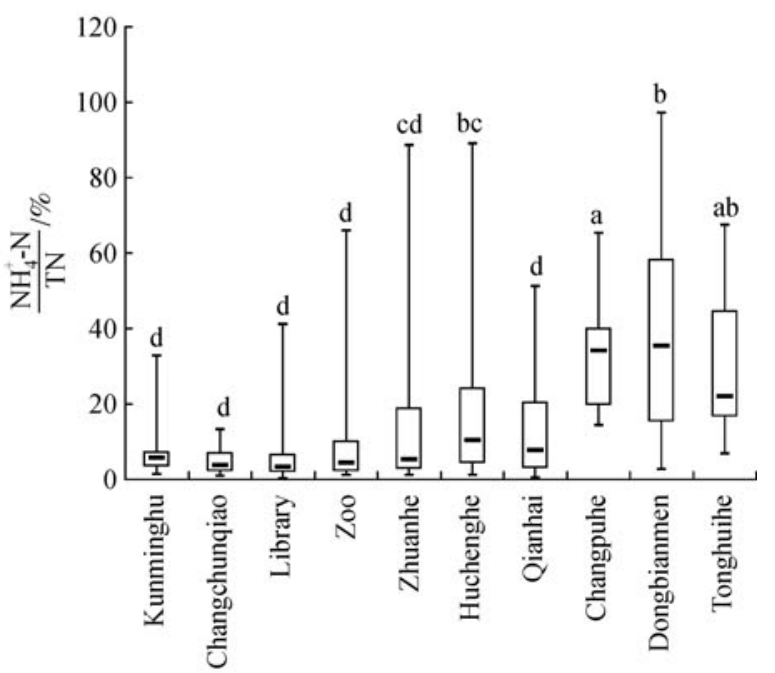

(f) 


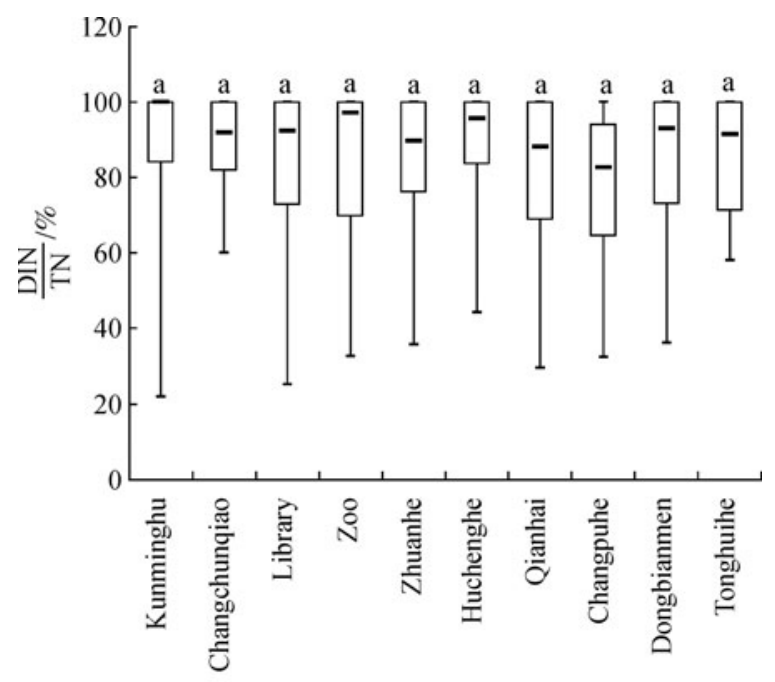

(g)

Fig. 2 Spatial variation in $\mathrm{NO}_{3}^{-}-\mathrm{N}, \mathrm{NH}_{4}^{+}-\mathrm{N}, \mathrm{DON}$, TN concentrations and nitrogen composition (labeled with different letters (a, b, c, d, e, f, g), respectively) in surface water in Beijing from 2009 to 2010 . Columns followed by different letters (a,b,c) are significantly different at $99 \%$ level and - denotes Class V guideline of surface water quality according to GB3838-2002. Boxplots illustrate the 25th, 50th, and 75th percentiles; the whiskers indicate the lowest and highest values

nitrogen, and total nitrogen concentrations at the Dongbianmen and Tonghuihe monitoring sites were significantly higher than those at the other eight monitoring sites $(P<0.01)$ (Figs. 2(a), 2(b), and 2(d)). The ammonium nitrogen and total nitrogen concentrations at sites Dongbianmen and Tonghuihe exceeded the Class $\mathrm{V}$ guideline for ammonium nitrogen $\left(2.0 \mathrm{mg} \cdot \mathrm{L}^{-1}\right)$ and total nitrogen $\left(2.0 \mathrm{mg} \cdot \mathrm{L}^{-1}\right)$ according to the national quality standards for surface waters of China [19](Figs. 2(b), and 2(d)). In general, downstream river water in the south-east of Beijing was more heavily polluted by nitrogen than the upstream river water in the north of Beijing.

Inorganic nitrogen (DIN) was the major nitrogen species in surface water in Beijing. At the 7 monitoring sites from Kunminghu Lake to Qianhai Lake, nitrate nitrogen accounted for about $65 \%$ to $80 \%$ of total nitrogen (Fig. 2(e)), while for the Dongbianmen and Tonghuihe monitoring sites, nitrate nitrogen accounted for about $47 \%$ to $56 \%$ of total nitrogen. The $\mathrm{NH}_{4}^{+}-\mathrm{N} / \mathrm{TN}$ ratios for the 7 monitoring sites from Kungminghu to Qianhai ranged from $4 \%$ to $19 \%$, but exceeded $30 \%$ in the Changpuhe, Dongbianmen and Tonghuihe monitoring sites (Fig. 2(f)). Although the $\mathrm{NO}_{3}-\mathrm{N} / \mathrm{TN}$ ratio tended to decline at the downstream monitoring sites, DIN was still the major nitrogen form, and ranged from $76 \%$ to $87 \%$. The DIN/TN ratio fell between $60 \%$ to $100 \%$ for all 10 monitoring sites (Fig. 2(g)).

\subsection{Seasonal variation of different species of nitrogen concentrations}

There were obvious seasonal variations in surface water $\mathrm{N}$ concentrations. (Fig. 3). Analysis showed that $\mathrm{NO}_{3}^{-}-\mathrm{N}$ and TN concentrations were lowest in the wet season from June to August, with the lowest concentrations corresponding with peak rainfall values (Figs. 3(a) and 3(d)). Highest $\mathrm{NO}_{3}^{-}-\mathrm{N}$ and $\mathrm{TN}$ concentrations occurred in the dry season during early spring and late autumn (Figs. 3(a) and 3(d)). At the Dongbianmen monitoring site, peak values of $\mathrm{NO}_{3}^{-}$ $-\mathrm{N}$ and $\mathrm{TN}$ reached $26 \mathrm{mg} \cdot \mathrm{L}^{-1}$ and $45 \mathrm{mg} \cdot \mathrm{L}^{-1}$, respectively, in November and April.

$\mathrm{NO}_{3}^{-}-\mathrm{N}$ and $\mathrm{TN}$ concentrations were negatively correlated with rainfall. At the Library, Zoo, Zhuanhe, Huchenghe, Qianhai and Dongbianmen monitoring sites, $\mathrm{NO}_{3}^{-}-\mathrm{N}$ concentrations were significantly and negatively correlated with mean monthly rainfall $(P<0.05)$ (Table 1$)$. At the Changchunqiao and Qianhai monitoring sites, total $\mathrm{N}$ concentrations were significantly and negatively correlated with mean monthly rainfall $(P<0.05)$ (Table 1$)$. However, the $\mathrm{NH}_{4}^{+}-\mathrm{N}$ concentrations were higher in the summer monsoon season, resulting in a significant positive correlation between rainfall and $\mathrm{NH}_{4}^{+}-\mathrm{N}$ in the Zhuanhe and Huchenghe Rivers $(P<0.01)$ (Table 1$)$. There were no significant correlations between rainfall and DON.

\subsection{The relationship of $\mathrm{NO}_{3}^{-}-\mathrm{N}$ to $\mathrm{Cl}^{-}$}

$\mathrm{Cl}^{-}$concentrations ranged from 14.8 to $86.0 \mathrm{mg} \cdot \mathrm{L}^{-1}$ (Fig. 4 (a)), and, as with $\mathrm{NO}_{3}^{-}-\mathrm{N}$ concentrations (Fig. 4(a), increased from upstream to downstream, with the $\mathrm{Cl}^{-}$ concentrations at the Dongbianmen and Tonghuihe downstream monitoring sites significantly higher than those at the upstream sites $(P<0.01)$. The average $\mathrm{NO}_{3}^{-}-\mathrm{N} / \mathrm{Cl}^{-}$ ratio was 0.08 for the Dongbianmen and Tonghuihe 


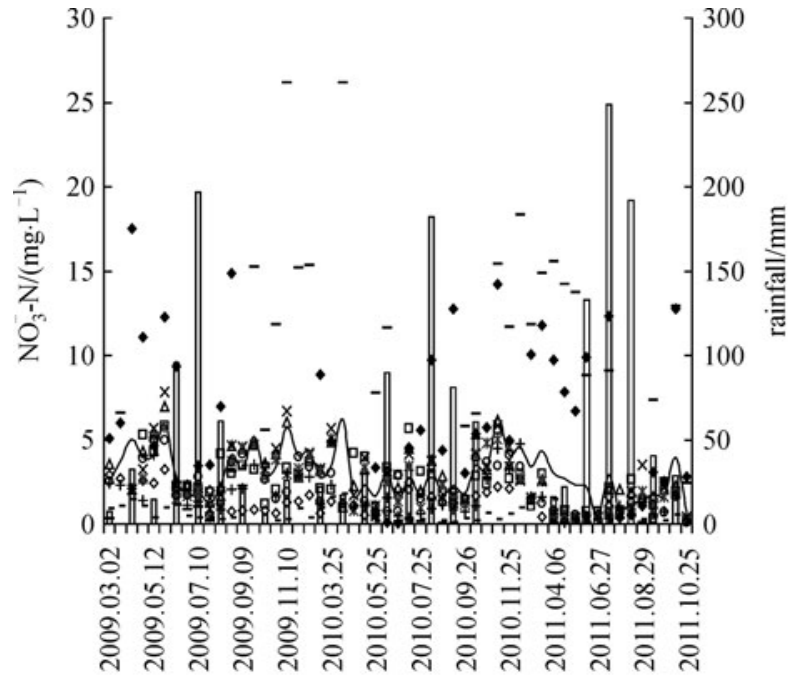

(a)

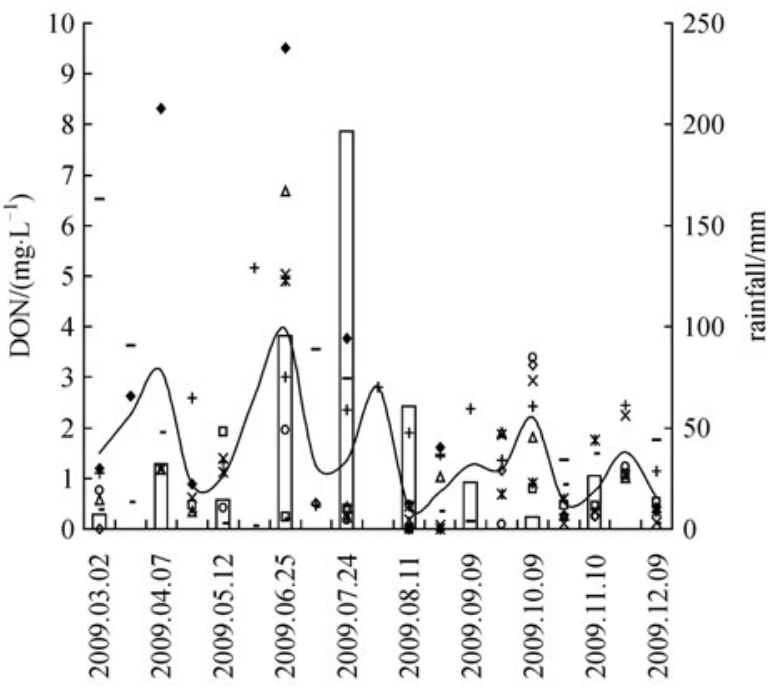

(c)

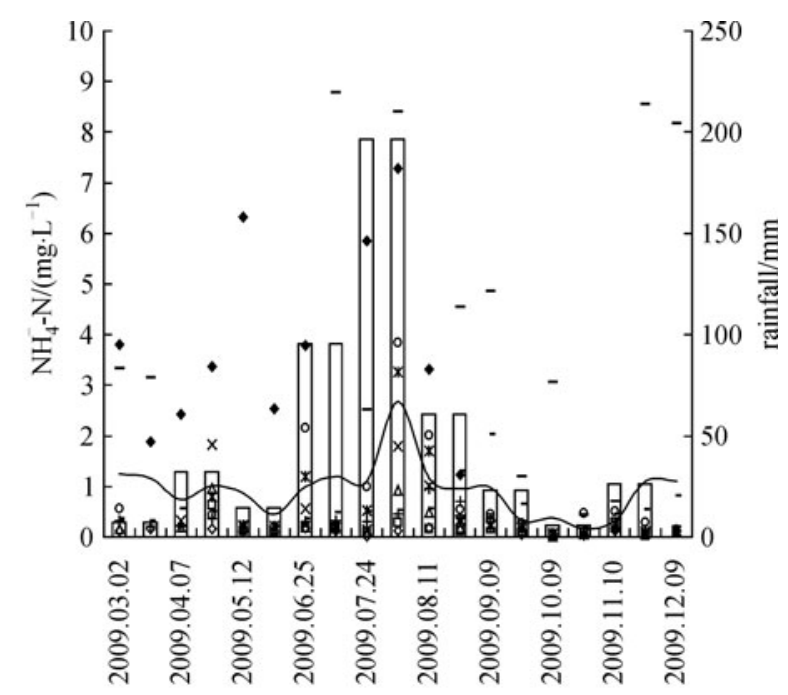

(b)

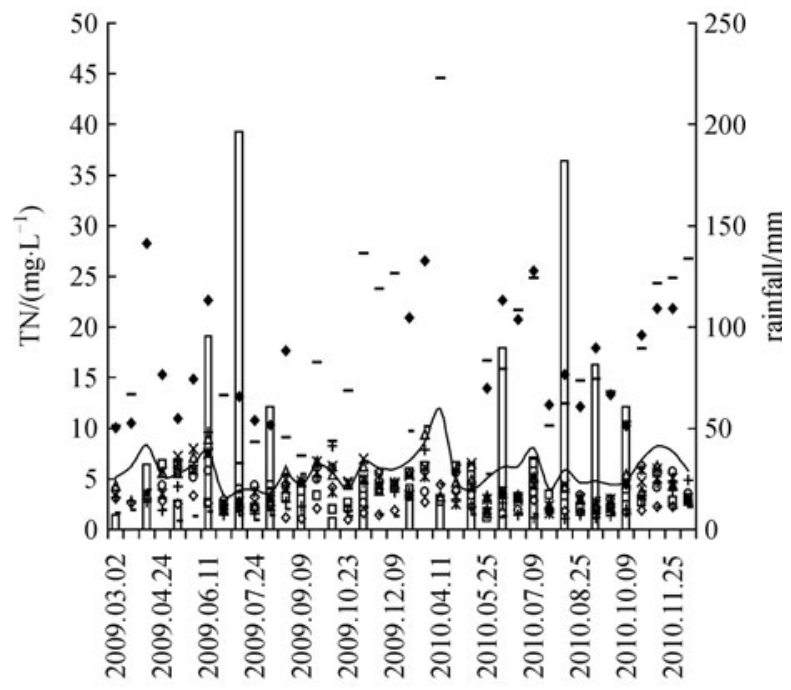

(d)

$$
\begin{array}{llll}
\square \text { Rainfall } & - \text { Average } & \bullet \text { Kungminghu } & \text { - Changchunqiao } \\
\Delta \text { Library } & \times \text { Zoo } & * \text { Zhuanhe } & \text { • Huchenghe } \\
+ \text { Qianhai } & \text { - Changpuhe } & \text { - Dongbianmen } & \text { * Tonghuihe }
\end{array}
$$

Fig. 3 Seasonal variation in $\mathrm{NO}_{3}^{-}-\mathrm{N}, \mathrm{NH}_{4}^{+}-\mathrm{N}, \mathrm{DON}$ and $\mathrm{TN}$ concentrations (labeled with $\mathrm{a}, \mathrm{b}, \mathrm{c}, \mathrm{d}$, respectively) in surface water in Beijing from 2009 to 2010 . Seasonal variation in $\mathrm{NO}_{3}^{-}-\mathrm{N}$ concentrations was assessed from 2009 to $2011, \mathrm{NH}_{4}^{+}-\mathrm{N}$ and $\mathrm{DON}$ from March to December in 2009, and TN from 2009 to 2010

monitoring sites, but was 0.12 from Kunminghu to Zhuanhe. Values for the $\mathrm{NO}_{3}^{-}-\mathrm{N} / \mathrm{Cl}^{-}$ratios were widely scattered at the Dongbianmen and Tonghuihe monitoring sites, but fell within a relatively restricted range at the upper sites (Fig. 4(b)). For all 10 monitoring sites $\mathrm{NO}_{3}^{-}-\mathrm{N}$ and $\mathrm{Cl}^{-}$concentrations were significantly positively correlated $\left(R^{2}=0.424, P<0.001\right)($ Fig. $4(\mathrm{~b}))$.

\subsection{Nitrate nitrogen isotopic characteristics}

Overall, the $\delta^{15} \mathrm{~N}_{\text {nitrate }}$ values surface water in urban
Beijing ranged from $-1.3 \%$ to $28.9 \%$. The average value was $11.5 \%(n=54)$, and the highest $\delta^{15} \mathrm{~N}_{\text {nitrate }}$ values found at the Dongbianmen monitoring site (from $16.6 \%$ to $26.3 \%$ ) (Fig. 5 (a). The $\delta^{15} \mathrm{~N}_{\text {nitrate }}$ values at Dongbianmmen were significantly higher than those at the other sites $(P<0.05)$ (Fig. 5 (b)). The mean $\delta^{15} \mathrm{~N}_{\text {nitrate }}$ values for the Changchunqiao and Tonghuihe monitoring sites were close to the median value for all sites, and ranged from $9.1 \%$ to $14.3 \%$ (Fig. 5 (b)). The average $\delta^{15} \mathrm{~N}_{\text {nitrate }}$ values for the Qianhai, Zhuanhe and Changpuhe monitoring sites ranged from $8.0 \%$ to $8.5 \%$ (Fig. 5 (b)), 
Table 1 Correlation coefficients between mean monthly rainfall and concentrations of different species of nitrogen in surface water in Beijing

\begin{tabular}{lcccc}
\hline monitoring site & $\mathrm{NO}_{3}^{-}-\mathrm{N}$ & $\mathrm{NH}_{4}^{+}-\mathrm{N}$ & $\mathrm{TON}$ & $(n=38)$ \\
& $(n=38)$ & $(n=19)$ & $-19)$ & -0.133 \\
\hline Kungminghu & 0.082 & -0.004 & -0.206 & $-0.342^{*}$ \\
Changchunqiao & -0.262 & 0.009 & 0.379 & -0.292 \\
Library & $-0.345^{*}$ & 0.492 & 0.641 & -0.283 \\
Zoo & $-0.366^{*}$ & 0.535 & 0.126 & -0.236 \\
Zhuanhe & $-0.484^{* *}$ & $0.849^{* *}$ & -0.193 & -0.239 \\
Huchenghe & $-0.415^{*}$ & $0.812^{* *}$ & 0.181 & $-0.44^{* *}$ \\
Qianhai & $-0.504^{* *}$ & 0.397 & -0.145 & -0.154 \\
Changpuhe & -0.355 & -0.023 & 0.242 & -0.335 \\
Dongbianmen & $-0.602^{* *}$ & 0.362 & 0.244 & -0.007 \\
Tonghuihe & -0.336 & 0.291 &
\end{tabular}

Note: $*$ and $* *$ represent statistically significant correlation at the $95 \%$ and $99 \%$ levels respectively

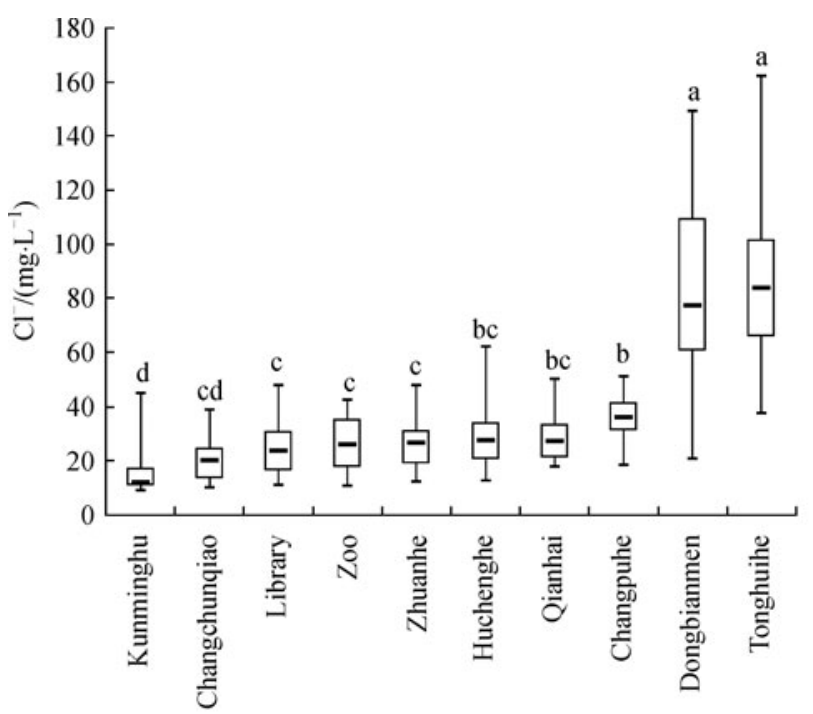

(a)

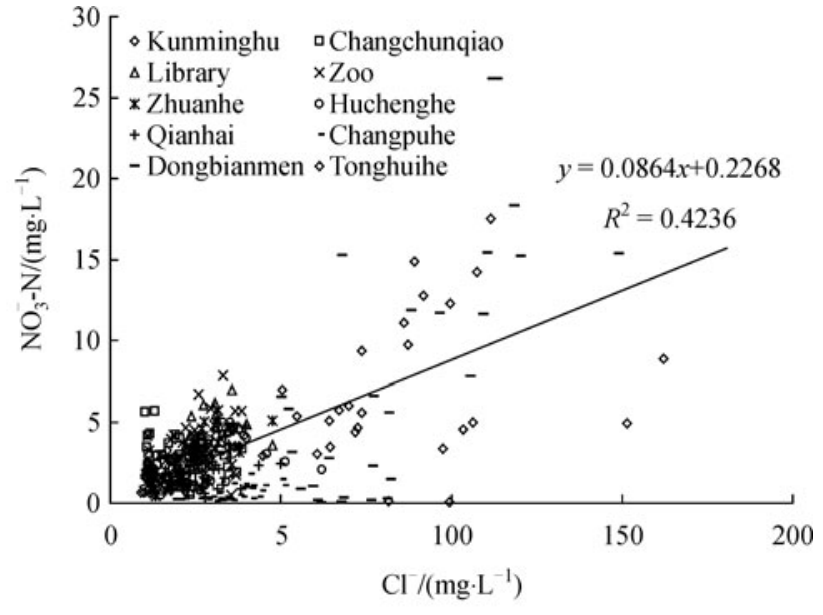

(b)

Fig. 4 Spatial variation in $\mathrm{Cl}^{-}$concentrations (a) and $\mathrm{Plot}_{\text {of }} \mathrm{NO}_{3}^{-}-\mathrm{N}$ versus $\mathrm{Cl}^{-}$(b) in surface water in Beijing City from 2009 to 2010. Columns followed by different letters (a, b, c) are significantly different at the $99 \%$ level. Boxplots illustrate the 25th, 50th, and 75 th percentiles; the whiskers indicate the lowest and highest values

and were significantly lower than those at the other sites $(P<0.05)$ (Fig. 5 (b)).

\section{Discussion}

\subsection{Characteristics of nitrogen pollution}

Surface water in urban Beijing is seriously polluted by nitrogen which indicates that surface water in urban Beijing is very obviously affected by human activities. Surface water functioning is impaired by the high $\mathrm{NH}_{4}^{+}-\mathrm{N}$ and TN concentrations, both of which exceeded the Class $\mathrm{V}$ guideline of the Chinese National Quality Standards for Surface Waters [19]. When compared with the TN concentrations of rivers and lakes in the Beijing metropolitan area in 2003, at which point they were all below $2 \mathrm{mg}$ $\cdot \mathrm{L}^{-1}$ [17], TN concentrations showed an increasing trend. The TN concentrations reported in this study are higher than those in the Taihu lake region [26], in the Haicheng river basin [27] and in the Beijiang river in south China [28], but close to the TN level of the Thames river in the UK [29], and of stream water in Pennsylvania, USA [30]. These increasing TN concentrations may be due to intensification of human activities caused by urbanization, and agrees with other studies which have shown that urbanization results in elevated $\mathrm{TN}$ and $\mathrm{NO}_{3}^{-}-\mathrm{N}$ concentrations in watersheds in developing areas [31,32], and that urbanization soon takes over as the major source of nitrogen in urban freshwater ecosystems [27]. 


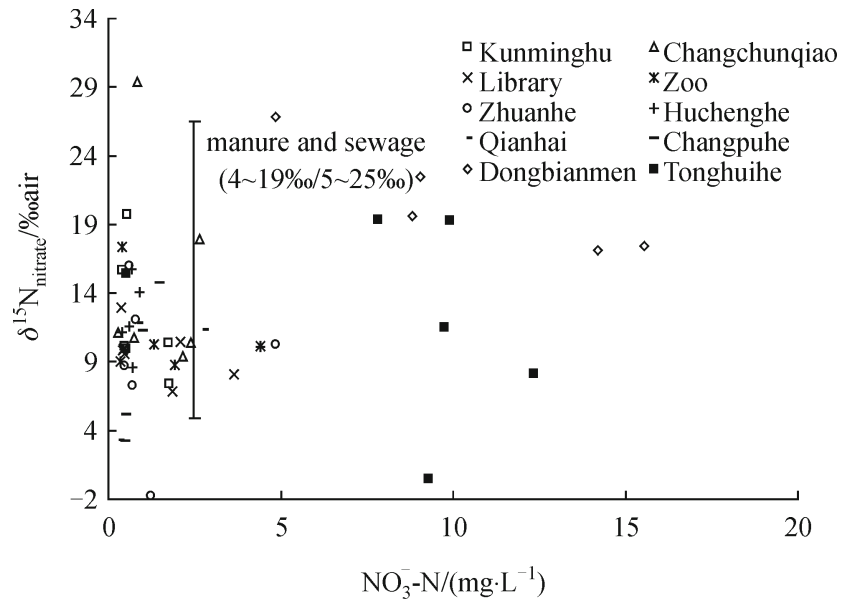

(a)

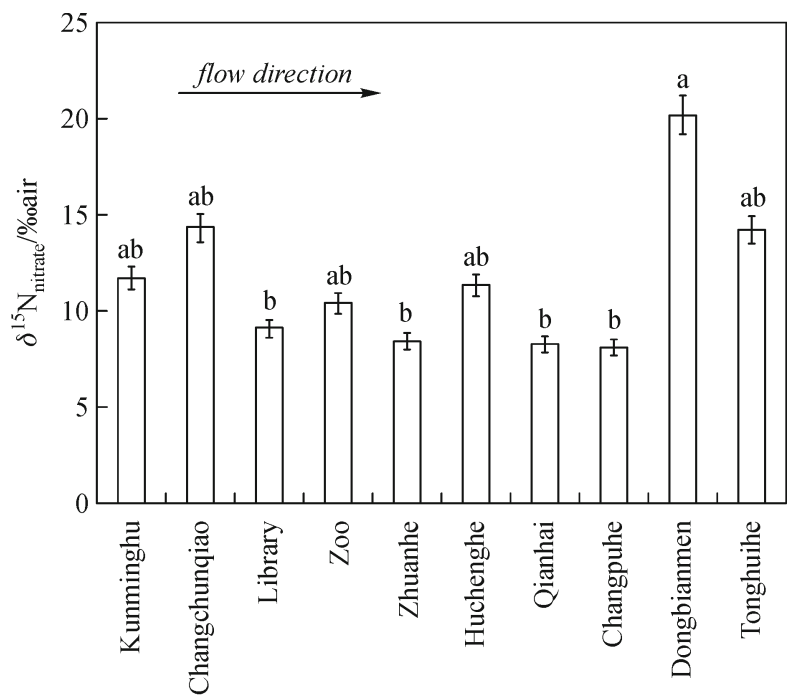

(b)

Fig. 5 Cross-plot of the $\delta^{15} \mathrm{~N}$ composition of nitrate versus $\mathrm{NO}_{3}^{-}-\mathrm{N}$ concentrations (a) and the $\delta^{15} \mathrm{~N}$ composition of nitrate versus different sites (b) for surface water in Beijing. The isotope values relate to samples collected in October 2010 and from April to August 2011. Columns followed by different letters $(a, b)$ are significantly different at $95 \%$ level

There were significant spatial variations in nitrogen concentrations in Beijing. Generally speaking, nitrogen pollution was mainly confined to the downstream areas in the south-east of the Beijing urban area. The higher values of the different nitrogen forms at the Dongbianmen and Tonghuihe monitoring sites suggest the presence of obvious inputs of pollutants in the vicinity of the monitoring sites. Indeed, the higher population density around the Dongbianmen and Tonghuihe Rivers compared to the other monitoring sites may have resulted in a higher input of municipal sewage to the surface water. In contrast, concentrations of the different nitrogen forms were low in the upstream region due to few anthropogenic inputs. Results from this study are comparable to those for the Shiyang River, which, downstream of Wuwei City, was reported to be seriously polluted by nitrogen [33]. Perona et al. [34] reported that high surface water nitrogen concentrations were consistent with high population densities, mainly due to the increasing discharges of domestic sewage.

The increase in the $\mathrm{NH}_{4}^{+}-\mathrm{N} / \mathrm{TN}$ ratio from upstream to downstream in Beijing's rivers may be due to the increasing residential development, and agrees with what has been found in other studies, for example, Chen et al. [26] found that the $\mathrm{NH}_{4}^{+}-\mathrm{N}$ concentrations in surface water near residential areas were higher than those for the other areas. Results from this study show that, as population and residential density increased from the north-west to the south-east of Beijing, there was a corresponding increase in nitrogen pollution.

Examination of seasonal patterns in nitrogen concentrations showed that $\mathrm{NO}_{3}^{-}-\mathrm{N}$ and $\mathrm{TN}$ concentrations were high in the dry season and low in wet season, which is consistent with the results of other similar studies. For example, Chen et al. [35] observed seasonal variations in surface water nitrogen concentrations in the Beijing Yuqiao reservoir, as did Zhang and Schilling [36], in their study of the Raccoon River in the USA. Withers and Lord [37] also reported that, in environments with low permeability surfaces (such as are found in urban areas), $\mathrm{NO}_{3}^{-}-\mathrm{N}$ concentrations in surface water tended to fall during high flow periods. Further, Mulliss et al. [38] reported that pollutant concentrations decreased as storm discharges increased. In-river processes may play a role in controlling river $\mathrm{NO}_{3}^{-}-\mathrm{N}$ and $\mathrm{TN}$ concentrations. For example, the lower $\mathrm{NO}_{3}^{-}-\mathrm{N}$ and $\mathrm{TN}$ values observed in summer may be attributable to biologic uptake of nitrogen in the river [36,39]; while higher values of $\mathrm{NO}_{3}^{-}-\mathrm{N}$ and $\mathrm{TN}$ in winter may be due to reduced plant and microbial uptake of nitrogen [40]. $\mathrm{NO}_{3}^{-}-\mathrm{N}$ pollution in surface water in Beijing is mainly from point sources, and, where point sources are important, river water $\mathrm{NO}_{3}^{-}-\mathrm{N}$ concentrations may be high during baseflow conditions [29].

Seasonal variation in $\mathrm{NH}_{4}^{+}-\mathrm{N}$ concentrations is probably mainly due to inputs of surface runoff with high $\mathrm{NH}_{4}^{+}-\mathrm{N}$ contents. Rainfall and DON were not significantly correlated, which may be due to the intense nitrification in summer which is known to promote biologic activities [41].

\subsection{Source identification of nitrogen pollution}

Potential sources of $\mathrm{NO}_{3}^{-}-\mathrm{N}$ in surface water in urban areas are sewage, fertilizer, manure, soil nitrogen and atmospheric deposition [42]. $\mathrm{Cl}^{-}$is a good indicator of sewage impacts because it is not subject to physical, chemical, and 
biologic processes [43] and as such, the $\mathrm{NO}_{3}^{-}-\mathrm{N} / \mathrm{C1}^{-}$ratio, combined with the isotopic method, has proved to be a useful hydro-chemical indicator to detect sources of $\mathrm{NO}_{3}^{-}$ $-\mathrm{N}$ in different ecosystems [44-46]. Values of the $\mathrm{NO}_{3}^{-}$$\mathrm{N} / \mathrm{Cl}^{-}$ratio for this study were consistent with those reported by Wakida and Lerner [5]. Also the $\mathrm{NO}_{3}^{-}-\mathrm{N} / \mathrm{C} 1$ ratios at Dongbianmen and Tonghuihe (0.08) are similar to the $\mathrm{NO}_{3}^{-}-\mathrm{N} / \mathrm{Cl}^{-}$ratios of the city sewage, which averaged 0.06 [47]. The close relationship of $\mathrm{NO}_{3}^{-}-\mathrm{N} / \mathrm{Cl}^{-}$may be due to anthropogenic sources of $\mathrm{Cl}^{-}$, possibly related to municipal sewage $[48,49]$. The domestic sewage discharge from Beijing was about 0.9 billion tons in 2009, which accounted for $90 \%$ of the city's wastewater discharge, and this figure continues to increase year by year in line with the continuing growth in population.

The $\delta^{15} N_{\text {nitrate }}$ values for the 10 monitoring sites mainly ranged between $4 \%-19 \%$, which are characteristic of manure and sewage (Fig. 5 (a)). Since there was little manure application to the urban soil and very few manure inputs to the surface water, this result indicates that the most likely source of $\mathrm{NO}_{3}^{-}-\mathrm{N}$ in the surface water of Beijing was domestic sewage, with only a minor contribution from soil organic matter or atmospheric deposition.

In the upstream region, from the Kunminghu to Changpuhe monitoring sites, mean $\delta^{15} N_{\text {nitrate }}$ values for surface water were close to the upper limit for atmospheric deposition and the lower limit for sewage, and were low when compared with those for the Dongbianmen and Tonghuihe monitoring sites. Nitrogen deposition is dominated by $\mathrm{NO}_{3}^{-}-\mathrm{N}$, with a $\mathrm{NH}_{4}^{+}-\mathrm{N} / \mathrm{NO}_{3}^{-}-\mathrm{N}$ ratio of 0.79 [50]. Atmospheric nitrogen deposition rates for Beijing have been estimated at $75.13 \mathrm{mg} \cdot \mathrm{m}^{-2}$, and, from June to September 2009, showed a significantly increasing trend [51]. Other authors have reported that direct runoff of atmospheric $\mathrm{NO}_{3}^{-}-\mathrm{N}$, mobilized from impervious surfaces, is an important source of $\mathrm{NO}_{3}^{-}-\mathrm{N}$ in urban watersheds during storm events $[1,30,52]$. In Beijing, atmospheric nitrogen deposition may account for a larger proportion of nitrogen pollution in the upper stream region relative to the downstream reaches, where the contribution from sewage was higher.

In general, $\delta^{15} N_{\text {nitrate }}$ values at the downstream monitoring sites (Dongbianmen and Tonghuihe) fell within the range of sewage with relatively high $\mathrm{NO}_{3}^{-}-\mathrm{N}$ concentrations, and may be explained by the fact that the population density near the Dongbianmen and Tonghuihe monitoring sites was somewhat higher than that of the other eight monitoring sites from Kungminghu to Changpuhe [53]. The $\delta^{15} \mathrm{~N}_{\text {nitrate }}$ values for Dongbianmen and Tonghuihe (which ranged from $9.1 \%$ to $14.3 \%$ ) fell within the expected range for sewage (from 6\%o to $14 \%$ ) [54]. Results for this study showed that the main source of surface water $\mathrm{NO}_{3}^{-}-\mathrm{N}$ may be domestic sewage at the downstream monitoring sites, which agrees with the results of Xie et al. [55] and Townsend et al. [56]. Processed wastewater from the Gaobeidian treatment plant is the main source of water to the Tonghui River. However, concentrations of nitrate and other forms of $\mathrm{N}$ were still high in this river, which may have been due to unidentified direct inputs of pollutants to the river in addition to the wastewater discharges. Alternatively the volume of wastewater may have exceeded the processing capacity of the wastewater treatment plant, which may have meant that partially treated waste water was discharged. In addition, the $\mathrm{NH}_{4}^{+}-\mathrm{N}$ in directly discharged sewage may have been nitrified to $\mathrm{NO}_{3}^{-}-\mathrm{N}$, in the presence of high $\mathrm{DO}$, which may have further contributed to the increased $\mathrm{NO}_{3}^{-}-\mathrm{N}$ concentrations [27]. The $\delta^{15} \mathrm{~N}_{\text {nitrate }}$ values of the surface water were in the expected range of $\delta^{15} \mathrm{~N}_{\text {nitrate }}$ values for animal wastes, and ranged from $3 \%$ to $13 \%$ [57]. The high $\delta^{15}$ $\mathrm{N}_{\text {nitrate }}$ values in Dongbianmen, which were greater than $25 \%$, may also be indicative of denitrification in surface water [58-60].

\section{Conclusions}

Surface water in Beijing is seriously polluted by inorganic nitrogen, with $\mathrm{NH}_{4}^{+}-\mathrm{N}$ and $\mathrm{TN}$ concentrations all exceeding the Class $\mathrm{V}$ guidelines given by the Chinese National Quality Standards for Surface Waters (GB3838-2002). Significant spatial variations in nitrogen concentrations suggest that surface water is very seriously polluted in the south-east of Beijing City. Human activities mainly controlled the inorganic nitrogen distribution in surface water in Beijing, with higher $\mathrm{NO}_{3}^{-}-\mathrm{N}$ and ammonia concentrations near residential and commercial areas.

Examination of seasonal variation showed that $\mathrm{NO}_{3}^{-}-\mathrm{N}$ and TN concentrations were high in the dry season and low in the wet season, which may be the result of point-source pollution and rainfall dilution. $\mathrm{NO}_{3}^{-}-\mathrm{N} / \mathrm{Cl}^{-}$and $\delta^{15} \mathrm{~N}_{\text {nitrate }}$ values showed that the main $\mathrm{NO}_{3}^{-}-\mathrm{N}$ source in the downstream reaches of Beijing was domestic sewage, while in the upper reaches, nitrate mainly derived from atmospheric deposition and, to a lesser degree, sewage.

The results from this study provide useful information for controlling sources of nitrogen to surface water in urban Beijing and eutrophication, and could contribute toward the implementation of sustainable environmental management in Beijing urban surface water. Results also suggest that investment into increased wastewater treatment facilities should be focused in the south-east part of Beijing. Further, the processing capacity of existing treatment plants should be increased, and the sewage treatment processes should be improved, so that wastewater treatment plant discharges are less polluting.

Acknowledgements This research was supported by the Knowledge Innovation Program of the Chinese Academy of Sciences (KZCX2-EW310 ) and the National Natural Science Foundation of China (Grant Nos. 41171153, 40901265, and 41030744). 


\section{References}

1. Silva S R, Ging P B, Lee R W, Ebbert J C, Tesoriero A J, Inkpen E L. Forensic applications of nitrogen and oxygen isotopes in tracing nitrate sources in urban environments. Environmental Forensics, 2002, 3(2): 125-130

2. Seiler R L. Combined use of ${ }^{15} \mathrm{~N}$ and ${ }^{18} \mathrm{O}$ of nitrate and ${ }^{11} \mathrm{~B}$ to evaluate nitrate contamination in ground water. Applied Geochemistry, 2005, 20(9): 1626-1636

3. Helmut K. Soil and groundwater contamination and remediation technology in Europe. In: Sato K, ed. Groundwater updates. Hong Kong: Springer, 2000

4. Benkovitz1 C M, Scholtz M T, Pacyna J, Tarrasón L, Dignon J, Voldner E C, Spiro P A, Logan J A, Graedel T E. Global gridded inventories of anthropogenic emissions of sulfur and nitrogen. Journal of Geophysical Research, 1996, 101(D22): 29239-29253

5. Wakida F T, Lerner D N. Non-agricultural sources of groundwater nitrate: a review and case study. Water Research, 2005, 39(1): 3-16

6. Mueller D K, Spahr N E. Nutrients in Streams and Rivers Across the Nation-1992-2001. Geological Survey Scientific Investigations Report, Washington, D C, 2006

7. Kaushal S S, Lewis W M Jr, McCutchan J H Jr. Land use change and nitrogen enrichment of a Rocky Mountain watershed. Ecological Applications, 2006, 16(1): 299-312

8. Groffman P M, Law N L, Belt K T, Band L E, Fisher G T. Nitrogen fluxes and retention in urban watershed ecosystems. Ecosystems (New York, N.Y.), 2004, 7(4): 394-403

9. He B, Kanae S, Oki T, Hirabayashi Y, Yamashiki Y, Takara K. Assessment of global nitrogen pollution in rivers using an integrated biogeochemical modeling framework. Water Research, 2011, 45(8): 2573-2586

10. Hu X F, Xu S Y, Chen Z L, Gao X J, Shen M N, Wang S P. Characteristics of nitrogen and phosphorus pollution in the middle and small creeks, suburban Shanghai. Environmental Sciences, 2001, 22(6): 66-71 (in Chinese)

11. Xiong D Q, Du X M, Tang W H, Huang M X, Gu Q B, Guo L J, Li F S. Nitrogen distribution in the water of the Haihe River mainstream and estuary seawater and its relationship with water dissolved oxygen levels. Research of Environmental Sciences, 2005, 18(3): 14 (in Chinese)

12. Yang W B, Wang G X, Zhang L M, Cao Y, Pan G Q. On temporalspatial var iability of water quality and environmental stress of Kuncheng Lake in Changshu City. Journal of Natural Resources, 2007, 22(1): 185-192 (in Chinese)

13. Lang H O, Zhou J, He Z, Xie X P, Jing Z G, Yang L H. The spatial characters of surfacewater quality and its controlling factors in Xi'an City. Journal of Arid Land Resources and Environment, 2009, 23 (2): 21-28 (in Chinese)

14. Fu G Y, Yu Y, Ye H P, Chen F Z. Nitrogen and phosphorus pollution of river in urban area of Guangzhou. Water Resources Protection, 2010, 26(1): 24-35 (in Chinese)

15. Zhang Z B, Shi X L, Yang X Y, Liu G J, Zhao Y J, Liu X J. The water quality comparative study on the West Lake (Hangzhou) and Hangzhou urban section of Beijing-Hangzhou Grand Canal. Journal of Hangzhou Normal University (Natural Science Edition), 2011, 10
(1): 59-63

16. Jing $\mathrm{H} \mathrm{W}$. An analysis of the causes and control methods for surface water pollution in Beijing. Urban Environment \& Urban Ecology, 2006, 19(4): 17-19 (in Chinese)

17. Du G S, Wu Y M, Yang Z S, Wu D W, Liu J. Analysis of water quality on urban rivers and lakes in Beijing. Journal of Lake Science, 2005, 17(4): 373-377 (in Chinese)

18. Tong Y F. Re-discussion on population carry-capacity of water resources in Beijing. Social Science of Beijing, 2011, 5: 22-28 (in Chinese)

19. China Ministry of Environmental Protection, China General Administration of Quality Supervision and Quarantine. Environmental Quality Standards for Surface Water (GB3838-2002). Beijing: China Ministry of Environmental Protection, 2002 (in Chinese)

20. Silva S R, Kendall C, Wilkisonb D H, Zieglerc A C, Changa C C Y, Avanzinoa R J. A new method for collection of nitrate from fresh water and the analysis of nitrogen and oxygen isotope ratios. Journal of Hydrology (Amsterdam), 2000, 228(1-2): 22-36

21. Durka W, Schulze E D, Gebauer G, Voerkelius S.Effects of forest decline on uptake and leaching of deposited nitrate determined from ${ }^{15} \mathrm{~N}$ and ${ }^{18} \mathrm{O}$ measurements. Nature, 1994, 372(22/29):765-767

22. Kendall C, Elliott E M, Wankel S D. Tracing anthropogenic inputs of nitrogen to ecosystems. In: Michener, R H, Lajtha K, eds. Stable Isotopes in Ecology and Environmental Science. London: Blackwell Publishing, 2007

23. Flipse W J, Bonner F T. Nitrogen-isotope ratios of nitrate in ground water under fertilized fields, Long Island, New York. Ground Water, 1985, 23(1): 59-67

24. Xue D M, Botte J, De Baets B, Accoe F, Nestler A, Taylor P, Van Cleemput $\mathrm{O}$, Berglund M, Boeckx P. Present limitations and future prospects of stable isotope methods for nitrate source identification in surface- and groundwater. Water Research, 2009, 43(5): 11591170

25. Xiao H Y, Liu C Q. Nitrogen isotope studies on seasonal nitrogen pollution of inflowing rivers of Hongfeng Lake, Guizhou Province. Earth and Environment, 2004, 32(1): 71-75 (in Chinese)

26. Chen X M, Wo F, Chen C, Fang K. Seasonal changes in the concentrations of nitrogen and phosphorus in farmland drainage and groundwater of the Taihu Lake region of China. Environmental Monitoring and Assessment, 2010, 169(1-4): 159-168

27. Bu H M, Meng W, Zhang Y. Nitrogen pollution and source identification in the Haicheng River basin in Northeast China. The Science of the Total Environment, 2011, 409(18): 3394-3402

28. Chen F J, Jia G D, Chen J Y. Nitrate sources and watershed denitrification inferred from nitrate dual isotopes in the Beijiang River, South China. Biogeochemistry, 2009, 94(2): 163-174

29. Neal C, Jarvie H P, Neal M, Hill L, Wickham H. Nitrate concentrations in river waters of the upper Thames and its tributaries. The Science of the Total Environment, 2006, 365(13): $15-32$

30. Buda A R, de Walle D R. Dynamics of stream nitrate sources and flow pathways during stormflows on urban, forest and agricultural watersheds in central Pennsylvania, USA. Hydrological Processes, 2009, 23(23): 3292-3305 
31. Hill A R. Streams phosphorus exports from catchments with contrasting land uses in southern Ohio. Journal of the American Water Resources Association, 1981, 17(4): 627-634

32. Osborne L, Wiley M. Empirical relationships between land use/ cover patterns and stream water quality in an agricultural watershed. Journal of Environmental Management, 1988, 26(1): 9-27

33. Ma J Z, Ding Z Y, Wei G X, Zhao H, Huang T M. Sources of water pollution and evolution of water quality in the Wuwei basin of Shiyang River, Northwest China. Journal of Environmental Management, 2009, 90(2): 1168-1177

34. Perona E, Bonilla I, Mateo P. Spatial and temporal changes in water quality in a Spanish river. The Science of the Total Environment, 1999, 241(1-3): 75-90

35. Chen L D, Fu B J, Zhang S R, Qiu J, Yang F L. Seasonal change of solvable nitrogen in surface water of Yuqiao reservoir basin. China Environmental Science, 2003, 23(2): 210-214 (in Chinese)

36. Zhang Y K, Schilling K. Temporal variations and scaling of streamflow and baseflow and their nitrate-nitrogen concentrations and loads. Advances in Water Resources, 2005, 28(7): 701-710

37. Withers P J, Lord E I. Agricultural nutrient inputs to rivers and groundwaters in the UK: policy, environmental management and research needs. The Science of the Total Environment, 2002, 282 283(23): 9-24

38. Mulliss R M, Revitt D M, Shutes R B. The impacts of urban discharges on the hydrology and water quality of an urban watercourse. The Science of the Total Environment, 1996, 189190: 385-390

39. Herpe Y V, Troch P A. Spatial and temporal variations in surface water nitrate. Hydrological Processes, 2000, 14(14): 2439-2455

40. Miller J D, Adamson J K, Hirst D. Trends in stream water quality in Environmental Change Network upland catchments: the first 5 years. The Science of the Total Environment, 2001, 265(1-3): 2738

41. Bellos D, Sawidis T, Tsekos I. Nutrient chemistry of River Pinios (Thessalia, Greece). Environment International, 2004, 30(1): 105115

42. Nestler A, Berglund M, Accoe F, Duta S, Xue D M, Boeckx P, Taylor P. Isotopes for improved management of nitrate pollution in aqueous resources: review of surface water field studies. Environmental Science and Pollution Research International, 2011, 18(4): $519-533$

43. Liu C Q, Li S L, Lang Y C, Xiao H Y. Using $\delta^{15} \mathrm{~N}$ - and $\delta^{18} \mathrm{O}$-values to identify nitrate sources in karst ground water, Guiyang, southwest China. Environmental Science \& Technology, 2006, 40(22): 69286933

44. Lee K S, Bong Y S, Lee D, Kim Y, Kim K. Tracing the sources of nitrate in the Han River watershed in Korea, using $\delta^{15} \mathrm{~N}-\mathrm{NO}_{3}^{-}$and $\delta^{18} \mathrm{O}-\mathrm{NO}_{3}^{-}$values. The Science of the Total Environment, 2008, 395(2-3): 117-124

45. Li S L, Liu C Q, Li J, Liu X, Chetelat B, Wang B, Wang F. Assessment of the sources of nitrate in the Changjiang River, China using a nitrogen and oxygen isotopic approach. Environmental Science \& Technology, 2010, 44(5): 1573-1578

46. Katz B G, Chelette A R, Pratt T R. Use of chemical and isotopic tracers to assess nitrate contamination and ground-water age,
Woodville Karst Plain, USA. Journal of Hydrology (Amsterdam), 2004, 289(1-4): 36-61

47. Zhang C Y, Wang Z, Cheng X X. Studies of nitrogen isotopes in sources of nitrate pollution in groundwater beneath the city of Zhangye. Journal of Arid Land Resources and Environment, 2004, 18(1): 79-85 (in Chinese)

48. Panno S V, Hackley K C, Hwang H H, Kelly W R. Determination of the sources of nitrate contamination in karst springs using isotopic and chemical indicators. Chemical Geology, 2001, 179(1-4): 113128

49. Kelly W R, Panno S V, Hackley K C, Hwang H H, Martinsek A T, Markus M. Using chloride and other ions to trace sewage and road salt in the Illinois Waterway. Applied Geochemistry, 2010, 25(5): 661-673

50. Zhang Y, Liu X J, Zhang F S, Ju X T, Zou G Y, Hu K L. Spatial and temporal variation of atmospheric nitrogen deposition in North China Plain. Acta Ecologica Sinica, 2006, 26(6): 1633-1638 (in Chinese)

51. Wang D X, Zhao P S, Zhang Y X, Zhang L H. Atmospheric nitrogen deposition in urban area of Beijing. Environmental Sciences, 2010, 31(9): 1987-1992 (in Chinese)

52. Ging P B, Lee R W, Silva S R. Water chemistry of Shoal Creek and Waller Creek, Austin, Texas, and potential sources of nitrate. U.S. Geological Survey Water-Resources Investigation Paper, 1996: 964167

53. Jia H F, Ma H T, Wei M J. Urban wetland planning: a case study in the Beijing central region. Ecological Complexity, 2011, 8(2): 213221

54. Zhang C Y, Zhang S, Li Z H, Liu S Y. Using nitrogen isotope techniques to identify the sources of the nitrate contamination to the groundwater beneath Shijiazhuang City. Advance in Earth Sciences, 2004, 19(2): 183-191 (in Chinese)

55. Xie Y X, Xiong Z Q, Xing G X, Sun G Q, Zhu Z L. Assessment of nitrogen pollutant sources in surface waters of Taihu Lake region. Pedosphere, 2007, 17(2): 200-208

56. Townsend S A, McCarthy M J, Brandes J A, Yang L Y, Zhang L, Gardner W S. Stable isotopic composition of nitrate in Lake Taihu, China, and major inflow rivers. Hydrobiologia, 2007, 194(3): 135140

57. Jia X F. Research on distributed pattern and sources of nitrate in groundwater of Shandong Province. Dissertation for the Master's Degree. Beijing: Chinese Academy of Agricultural Scienses, 2010 (in Chinese)

58. Panno S V, Hackley K C, Kelly W R, Hwang H H. Isotopic evidence of nitrate sources and denitrification in the Mississippi River, Illinois. Journal of Environmental Quality, 2006, 35(2): 495504

59. Bryan B A, Shearer G, Skeeters J L, Kohl D H. Variable expression of the nitrogen isotope effect associated with denitrification of nitrite. The Journal of Biological Chemistry, 1983, 258(14): 86138617

60. Jin Z F, Chen Y X, Wang F E, Ogura N. Detection of nitrate sources in urban groundwater by isotopic and chemical indicators, Hangzhou City, China. Environmental Geology, 2004, 45(7): $1017-1024$ 